\title{
Ireneusz Kurczyna
}

Związek Rewizyjny Banków Spółdzielczych im. F. Stefczyka w Warszawie

e-mail: kurczyna@zrbs.pl

\section{Lukasz Szydełko}

Politechnika Rzeszowska

e-mail: lukaszsz@prz.edu.pl

\section{RATINGI BANKÓW SPÓŁDZIELCZYCH - WYBRANE ASPEKTY}

\section{RATINGS OF COOPERATIVE BANKS - SELECTED ASPECTS}

DOI: $10.15611 /$ pn.2018.514.19

JEL Classification: G21, M41

Streszczenie: W Polsce na koniec 2017 r. liczba podmiotów prowadzących działalność bankową w sektorze bankowości spółdzielczej wynosiła 553. Występowanie tak dużej liczby banków spółdzielczych powoduje naturalną potrzebę dokonania porównań tych banków i ich oceny finansowej. Umożliwia to również w pewnym zakresie ocenę działań kadry zarządzającej przez członków spółdzielni i innych interesariuszy. Ratingi mogą być ustalane w ramach zdefiniowanych kategorii (zyskowność, aktywność, ryzyko kredytowe, płynność). Z punktu widzenia modelu stanowić one będą ratingi cząstkowe. Celem artykułu było przedstawienie możliwości budowy modelu ratingowego (oceny) banków spółdzielczych przy wykorzystaniu informacji pochodzących z ich sprawozdań finansowych. Realizacja tak postawionego celu wiązała się z wykorzystaniem krytycznego przeglądu literatury i uregulowań prawnych z zakresu rachunkowości jako metod badawczych.

Słowa kluczowe: ratingi banków spółdzielczych, banki spółdzielcze.

Summary: In Poland, at the end of 2017, the number of entities conducting banking activities in the cooperative banking sector was 553. The presence of such a large number of cooperative banks causes a natural need to make comparisons of these banks and their financial assessment. It also allows to some extent to assess the actions of the management team by members of cooperatives and other stakeholders. Taking into account these conditions, a cooperative banks rating model should be introduced. Ratings (from the point of view of the model partial ones) can be determined within defined categories (profitability, activity, credit risk, liquidity). The purpose of the article was to present the possibilities of building a rating model (assessment) of cooperative banks using information from their financial statements. Implementation of such a goal was related to the use of a critical review of literature and legal regulations in the field of accounting as research methods.

Keywords: ratings of cooperative banks, cooperative banks. 


\section{Wstęp}

W Polsce na koniec 2017 r. liczba podmiotów prowadzących działalność bankową wyniosła 616 , z czego największą liczbę stanowiły banki spółdzielcze - 553 podmioty. Banki komercyjne uplasowały się na drugim miejscu z liczbą 35 jednostek, a oddziałów instytucji kredytowych było 28.

Liczba banków spółdzielczych zmniejsza się sukcesywnie. Wśród głównych przyczyn takiego stanu rzeczy należy z pewnością wskazać połączenia i upadłości. Biorąc pod uwagę ostatnie 5 lat, można stwierdzić, że w wyniku połączeń liczba banków spółdzielczych zmniejszyła się o 16, natomiast upadłość doprowadziła do redukcji ich liczby o 2 podmioty (upadłość ogłoszono w stosunku do Banku Rzemiosła i Rolnictwa w Wołominie (SK Bank) oraz Banku Spółdzielczego w Nadarzynie).

Analizując aktywa podmiotów systemu finansowego na koniec 2017 r., można stwierdzić, że banki spółdzielcze posiadały aktywa o wartości 130,3 mld złotych, co stanowiło 5,1\% aktywów ogółem systemu finansowego i 7,3\% w sektorze bankowym [Raport o sytuacji banków w 2017 r.].

Występowanie tak dużej liczby banków spółdzielczych powoduje naturalną potrzebę dokonania porównań tych banków i ich oceny finansowej. Umożliwia to również w pewnym zakresie ocenę działań kadry zarządzającej przez członków spółdzielni i innych interesariuszy.

Informacje ratingowe mogą być również wykorzystywane przez instytucje nadzorujące system finansowy (w tym KNF, NBP, BFG), banki zrzeszające oraz wewnętrzne systemy ochrony instytucjonalnej funkcjonujące w strukturach banków spółdzielczych.

Dzięki tym informacjom możliwe jest porównanie banków spółdzielczych i poszukiwanie efektywniejszych rozwiązań, w tym poprawy efektywności zarządzania aktywami i konieczności ograniczania ryzyka (głównie ryzyka kredytowego i ryzyka płynności).

Celem artykułu jest przedstawienie możliwości budowy modelu ratingowego (oceny) banków spółdzielczych przy wykorzystaniu informacji pochodzących z ich sprawozdań finansowych. Realizacja tak postawionego celu wiązała się z wykorzystaniem krytycznego przeglądu literatury i uregulowań prawnych z zakresu rachunkowości jako metod badawczych.

\section{Banki spółdzielcze w Polsce}

Początki spółdzielczości bankowej sięgają połowy XIX wieku. Powstanie w 1844 r. spółdzielni spożywców w Rochdale w Anglii traktowane jest jako początek ruchu spółdzielczego w Europie [Mierzwa 2010].

W latach okupacji niemieckiej spółdzielczość polska w ogromnej części uległa zniszczeniu, dopiero po roku 1945 sektor spółdzielczy został poddany nacjonaliza- 
cji. Reaktywowane przedwojenne i tworzone nowe spółdzielnie zrzeszano w nowych strukturach państwowych.

Okres powolnej odbudowy polskiej spółdzielczości bankowej rozpoczął się wraz z „odwilżą” 1956 r. W 1957 r. powołano ogólnokrajowy Związek Spółdzielni Oszczędnościowo-Pożyczkowych jako centralę zrzeszanych w nim na zasadzie członkostwa spółdzielni. Funkcję centrali finansowej pełnił bank państwowy (NBP, później Bank Rolny). Reforma bankowości rozpoczęła się od wejścia w życie ustawy - Prawo bankowe z dnia 12 czerwca 1975 r. Utworzono Bank Gospodarki Żywnościowej, który przejął wszystkie uprawnienia działających dotychczas instytucji spółdzielczo-kredytowych, oszczędnościowych czy pożyczkowych. Spółdzielnie zobligowane zostały do używania nazwy „bank spółdzielczy” i zrzeszania się w BGŻ. Dopiero po roku 1989 rozpoczął się czas odradzania spółdzielczości bankowej i powrotu do mechanizmów gospodarki rynkowej. Spółdzielczość bankowa stawała się elementem demokratycznego społeczeństwa w kształtującym się państwie prawa [https://www.krs.org.pl].

W obecnych czasach banki spółdzielcze prowadzą operacje w Polsce głównie lokalnie (ograniczenie terytorialne prowadzenia działalności), nie mogą wykonywać samodzielnie określonych operacji bankowych (przy niektórych operacjach wymagana jest zgoda banku zrzeszającego) i są zmuszone przepisami prawa do zrzeszania się [Ustawa z 7 grudnia 2000]. Na dzień dzisiejszy występują dwa takie zrzeszenia. Pierwsze z nich zostało utworzone wokół Banku Polskiej Spółdzielczości, drugie związane jest ze Spółdzielczą Grupą Bankową.

Banki spółdzielcze coraz częściej muszą konkurować o klientów z bankami komercyjnymi [Rosa 2013; Siudek, Snarski, Chodera 2013; Zalewska (red.) 2013]. W wielu przypadkach banki komercyjne dzięki dużym nakładom inwestycyjnym rozwijają segment e-bankowości oraz tworzą struktury oparte na zasadach franchisingu [Dobosiewicz 2011]. Natomiast banki spółdzielcze mogą funkcjonować tylko na bazie:

1) polskiego kapitału,

2) bardzo dobrej znajomości rynków, na których funkcjonują,

3) indywidualnego podejścia do każdego ze swoich klientów.

To właśnie te wyróżniki sprawiają, że banki spółdzielcze w ostatnich latach bardzo się rozwinęły. Niemniej zakres ich działania, położenie geograficzne, inna grupa klientów czy ukierunkowanie na rozwój regionu nawet kosztem utraty rentowności są w wielu przypadkach specyficzne dla spółdzielczości bankowej i często wiążą się z wyższymi kosztami działania banków spółdzielczych. Mimo takiej sytuacji należy zauważyć, że w 2017 r. tylko sześć banków spółdzielczych na 553 odnotowało stratę netto, a sektor bankowy zgodnie z CRD IV/CRR spełniał wymogi regulacyjne w zakresie minimalnego poziomu funduszy własnych lub minimalnych współczynników kapitałowych [Golec 2016]. 


\section{Dobór wskaźników do ratingów banków spóldzielczych}

Opracowanie modelu do oceny banków spółdzielczych jest zagadnieniem skomplikowanym i wymaga przeprowadzenia analizy potrzeb odbiorców docelowych oceny ratingowej. Należy zwrócić uwagę w tym zakresie na fakt, że są różne możliwości rozbudowy modelu. Może być on ukierunkowany na ocenę ryzyka dla audytu, potrzeby KNF, systemu ochrony oraz potrzeb osób zarządzających i nadzorujących bank.

Ustalając rating, należy uwzględnić to, że ocena może być przygotowana na dwóch poziomach. Pierwszy to zintegrowany rating ogólny, będący w pewnym zakresie wypadkową ratingów cząstkowych. Drugi poziom to ratingi cząstkowe.

W ramach ratingów cząstkowych należy w pierwszej kolejności ustalić kategorię. Następnie dobierane są odpowiednie wskaźniki i wagi do nich. Ważnym elementem oceny jest także ustalenie, czy odniesienie jest do wzorcowych wskaźników, wskaźników grupowych (grup rówieśniczych) lub wskaźników całego sektora bankowego.

W ramach budowy modelu na podstawie przeprowadzonych analiz autorzy zaproponowali następujące założenia:

1. Ocena danego banku spółdzielczego odbywa się na tle innych banków spółdzielczych, a nie np. poprzez porównanie do banku komercyjnego. Należy przy tym przyjąć podział na cztery grupy rówieśnicze (proponowane są cztery grupy rówieśnicze z sumą bilansową do $50 \mathrm{mln}$ złotych, od 50 do $100 \mathrm{mln}$ złotych, od 100 do $200 \mathrm{mln}$ złotych oraz powyżej $200 \mathrm{mln}$ złotych). Takie podejście daje możliwość podziału banków spółdzielczych na trzy równe grupy po ok. 30\%, natomiast w grupie do 50 mln złotych liczba banków będzie wynosiła ok. 10\%.

2. Przyjęcie wskaźników wzorcowych i porównywanie do nich jest problematyczne. Wynika ze zmian istotnych w przepisach, w tym wyceny bilansowej i prezentacji niektórych kategorii w sprawozdaniu finansowym banków spółdzielczych. Przykładem mogą być zmiany w zakresie likwidacji odsetek zastrzeżonych i wpływ zmiany polityki rachunkowości na ujęcie tych zmian jako błędu w poprzednim okresie (inne ujęcie w przychodach i kosztach banku oraz wpływ na wskaźniki). Przyjęcie modelu opartego na ocenie w grupie rówieśniczej umożliwia poprawne odniesienie do wyników grupy rówieśniczej jako całości oraz do innego wybranego banku.

3. W modelu proponuje się przyjęcie pięcioletniego okresu w zakresie wykorzystywania danych do wyliczenia wskaźników. Wydłużony okres ze względu na wykorzystywanie modelu do zarządzania i oceny ryzyka miałby tylko znaczenie historyczne i mógłby powodować błędne wnioski. Przyjęcie krótszego okresu to z kolei ograniczenie w czasie możliwości analizy.

4. Rating będzie tworzony na podstawie analizy banków badanych przez Związek Rewizyjny Banków Spółdzielczych im. F. Stefczyka w Warszawie. Do oceny i opracowania modelu przyjęte będą wyniki z ok. 300 banków spółdzielczych.

5. W modelu zostaną wprowadzone cztery kategorie - ratingi cząstkowe: 
a) wskaźniki zyskowności - charakteryzują się koncentracją na efektywności działania, a głównym czynnikiem jest wypracowany zysk,

b) wskaźniki aktywności - zespół wskaźników wskazujący na rozwój i optymalizację zarządzania strukturą aktywów i pasywów,

c) wskaźniki ryzyka kredytowego - wskaźniki oceniające „apetyt” na ryzyko, pozwalają kontrolować ryzyka i utrzymywać wymogi kapitałowe,

d) wskaźniki płynności - mierniki stosowane do oceny ryzyka płynności i spełnienia wymogów w tym zakresie.

6. W modelu przyjęto oznaczenia literowe A, B, C lub D, znaki „+" lub "-, mają charakter pomocniczy i dodawane są w celu dokładniejszego określenia różnic ryzyka w jednej kategorii. Ocena ratingowa odbywa się zatem w dziewięciostopniowej skali:

a) A++ - wartości wskaźników uznane przez bank są lepsze od 95\% wartości wskaźników uzyskanych przez pozostałe banki (zbiór badanych banków przez Związek Rewizyjny im. F. Stefczyka w Warszawie),

b) A+ - wartości wskaźników uznane przez bank są lepsze od $85 \%$ wartości wskaźników uzyskanych przez pozostałe banki,

c) A - wartości wskaźników uznane przez bank są lepsze od $75 \%$ wartości wskaźników uzyskanych przez pozostałe banki,

d) A- - wartości wskaźników uznane przez bank są lepsze od $60 \%$ wartości wskaźników uzyskanych przez pozostałe banki,

e) B+ - wartości wskaźników uznane przez bank są lepsze od $40 \%$ wartości wskaźników uzyskanych przez pozostałe banki,

f) B - wartości wskaźników uznane przez bank są lepsze od $25 \%$ wartości wskaźników uzyskanych przez pozostałe banki,

g) B- - wartości wskaźników uznane przez bank są lepsze od 15\% wartości wskaźników uzyskanych przez pozostałe banki,

h) C - wartości wskaźników uznane przez bank są lepsze od 10\% wartości wskaźników uzyskanych przez pozostałe banki,

i) D - wartości wskaźników uznane przez bank mieszczą się w grupie 5\% najgorszych wartości wskaźników uzyskanych przez pozostałe banki.

Przyjęcie dziewięciostopniowej skali daje możliwość elastycznego podejścia. Zbyt mała lub zbyt duża skala może powodować z jednej strony mały wachlarz możliwości skalowania i wyboru, z drugiej strony skala o większej liczbie stopni mogłaby zaciemniać obraz i ocenę oraz powodować problemy z określeniem oceny dla danego banku. Zakładając, że proponowany model dotyczy grupy banków z sumą bilansową od 100 do 200 mln złotych (ok. 30\% banków), to w tej grupie byłoby ok. 163 banków i przykładowy podział wyglądałby następująco: w kategorii $\mathrm{A}++-8, \mathrm{~A}+-16, \mathrm{~A}-16, \mathrm{~A}^{-}-25, \mathrm{~B}+-33, \mathrm{~B}-25, \mathrm{~B}--16, \mathrm{C}-16$ i D -8 .

7. W ramach poszczególnych wskaźników dokonuje się oceny występujących $\mathrm{w}$ nich trendów (badanie tendencji na wskaźnikach w okresie pięciu lat), wprowadzając pięciostopniową skalę: 
a) St - podmiot charakteryzuje się dobrym poziomem analizowanego wskaźnika, brak istotnych odchyleń w całym analizowanym okresie w odniesieniu do wskaźników uzyskanych w grupie rówieśniczej,

b) St+ - podmiot charakteryzuje się dobrym poziomem analizowanego wskaźnika, brak istotnych odchyleń w całym analizowanym okresie w odniesieniu do wskaźników uzyskanych w grupie rówieśniczej, istnieje szansa poprawy wskaźnika w przyszłości, tj. poprawy pozycji w grupie,

c) Wz - duże prawdopodobieństwo poprawy wskaźnika w przyszłości,

d) St- - możliwość nieznacznego pogorszenia ratingu analizowanego wskaźnika w przyszłości,

e) $\mathrm{Sp}$ - duże prawdopodobieństwo spadku ratingu analizowanego wskaźnika w przyszłości.

W odniesieniu do niektórych wskaźników ze względu na ich charakter przyjęto inny niż opisywany model. Przyjmuje się w tym zakresie trzystopniowy model oceny dodatkowej:

a) NR - niskie ryzyko wystąpienia zagrożeń mających wpływ na analizowany obszar w przyszłości oraz analizowany wskaźnik,

b) SR - średnie ryzyko wystąpienia zdarzeń wpływających negatywnie na analizowany obszar oraz znaczących wahań na analizowany wskaźnik,

c) WR - wysokie ryzyko wystąpienia zdarzeń mających negatywny wpływ w analizowanym obszarze oraz wahań wskaźnika.

8. Wagi przypisane do poszczególnych kategorii ustala się w zależności od ukierunkowania ratingu, np. przy ocenie ryzyka (ryzyko będzie miało najwyższą wagę).

9. Do kategorii zyskowności proponowane są następujące wskaźniki:

a) ROE (rentowność kapitału własnego) = zysk netto/kapitał własny $* 100 \%$. Wskaźnik ze względu na specyfikę banków spółdzielczych, w przeciwieństwie do komercyjnych, będzie miał mniejszą wagę i znaczenie.

b) Marża na aktywach = wynik na działalności bankowej/suma bilansowa $* 100 \%$.

c) ROA - wynik finansowy netto/suma bilansowa, ten wskaźnik w bankowości spółdzielczej jest uznawany przez zarządy banków za główny miernik zyskowności banku.

d) $\mathrm{C} / \mathrm{I}=$ (koszty działania + amortyzacja)/ (wynik z działalności bankowej + pozostałe przychody operacyjne - pozostałe koszty operacyjne). Wskaźnik, na który szczególną uwagę zwraca KNF jako element kontroli kosztów w bankach spółdzielczych, gdzie wynagrodzenia mają dominujący udział w kosztach. Pozwala ocenić i kontrolować koszty działania banków spółdzielczych.

10. Do kategorii aktywności proponowane są następujące wskaźniki:

a) Kredyty/depozyty = (należności od sektora niefinansowego + należności od sektora budżetowego)/(zobowiązania wobec sektora niefinansowego + zobowiązania wobec sektora budżetowego. 
b) Kredyty do aktywów = obligo kredytowe/aktywa razem. Wskaźnik ten jest szczególnie istotny i wskazuje na aktywność banku w zakresie udzielania kredytów.

c) Dynamika sumy bilansowej - wskaźnik bardzo istotny. Brak wzrostu powyżej inflacji wskazuje na negatywne działania w zakresie zarządzania. Szczególne znaczenie ma w analizie dynamiki uzyskanie podobnych wielkości na przestrzeni kilku lat. Zbyt wysoka dynamika może wpłynąć niekorzystnie na wskaźniki dotyczące ryzyka kredytowego i apetytu na to ryzyko, duży spadek wskaźników adekwatności kapitałowej i problemy z utrzymaniem ich na odpowiednim poziomie.

d) Należności od sektora finansowego/aktywa razem. Wskaźnik, przy pomocy którego można określić poziom niewykorzystanych efektywnie aktywów.

11. Wskaźniki ryzyka kredytowego:

a) Wskaźnik ryzyka działalności kredytowej = kredyty zagrożone/obligo kredytowe.

b) Wskaźnik kredytów straconych = kredyty stracone/obligo kredytowe.

c) Współczynnik wypłacalności = kapitał własny banku netto/wartość aktywów i pozycji pozabilansowych ważonych ryzykiem. Wskazuje z jednej strony na wymagania odnośnie do posiadania minimalnych poziomów współczynników kapitałowych. Natomiast w sytuacji, gdy poziom tego współczynnika jest zbyt wysoki, oznacza to brak akcji kredytowej i ostrożnościowe podejście osób zarządzających bankiem spółdzielczym.

12. Wskaźniki ryzyka płynności:

a) Wskaźnik płynności krótkoterminowej (LCR) = aktywa płynne wysokiej jakości/całkowite wpływy netto w ciągu następnych 30 dni kalendarzowych.

b) Wskaźnik płynności strukturalnej (NSRF) = (funduszy własne i obce stabilne)/(aktywa niepłynne + aktywa o ograniczonej płynności (przy założeniu sytuacji kryzysowej)). Kluczowy w zakresie tych wskaźników jest fakt odchodzenia od mierników M1, M2 i M3. Spowodowane jest to zmianami prawnymi [Dziwok 2015; Flotyński 2017].

13. Każdy z opisanych wskaźników powinien mieć przypisaną wagę w zakresie swojej kategorii. Wszystkie wskaźniki należące do danej kategorii na podstawie otrzymanych wyników tworzą rating cząstkowy.

14. Każda kategoria następnie ma przypisaną wagę (każdy rating cząstkowy ma przypisaną wagę). Na podstawie wag i ratingów cząstkowych w ostateczności tworzy się końcowy ogólny rating banku spółdzielczego.

W praktyce ratingi ustalone w opisany sposób posłużyły do oceny ryzyka badania przez biegłych rewidentów (Związek Rewizyjny Banków Spółdzielczych im. F. Stefczyka w Warszawie) i pozwoliły określić ryzyko badania dla banku spółdzielczego oraz przygotować odpowiedni program badania. Umożliwiło to także ocenę banków na tle grupy i porównanie ich z podobnymi bankami spółdzielczymi. 


\section{Zakończenie}

W Polsce na koniec 2017 r. liczba podmiotów prowadzących działalność bankową w sektorze bankowości spółdzielczej wynosiła 553. Duża liczba banków spółdzielczych powoduje naturalną potrzebę dokonania porównań tych banków i ich oceny finansowej. Biorąc pod uwagę te wymagania, należy wprowadzić model ratingowy banków spółdzielczych.

Ratingi mogą być ustalane w ramach zdefiniowanych kategorii (zyskowność, aktywność, ryzyko kredytowe, płynność). Należy przy tym zauważyć, że na poziomie tych kategorii będą tworzone ratingi cząstkowe. Zostają im przypisane odpowiednie wagi. Na podstawie tych informacji jest ustalany całościowy ogólny rating danego banku spółdzielczego. W praktyce istnieje możliwość jego porównania $\mathrm{z}$ innym bankiem spółdzielczym lub określoną grupą banków spółdzielczych (grupą rówieśniczą).

\section{Literatura}

Dobosiewicz Z., 2011, Bankowość, Polskie Wydawnictwo Ekonomiczne, Warszawa.

Dziwok E., 2015, Metody pomiaru ryzyka płynności w banku komercyjnym, Studia Ekonomiczne. Zeszyty Naukowe Uniwersytetu Ekonomicznego w Katowicach, nr 238, s. 7-14.

Flotyński M., 2017, Wskaźnik stabilnego finansowania netto (NSFR) a zmiany w strukturze aktywów $i$ pasywów banku, Studia Ekonomiczne. Zeszyty Naukowe Uniwersytetu Ekonomicznego w Katowicach, nr 325, s. 45-57.

Golec M., 2016, Instytucje i ustugi bankowe, Wydawnictwo Wyższej Szkoły Bankowej w Poznaniu, Poznań

https://www.krs.org.pl/index.php/ruch-spodzielczy-sp-1235027509/historia (27.05.2018).

Mierzwa D., 2010, Przedsiębiorstwo spółdzielcze: tradycja i współczesność, Wydawnictwo Uniwersytetu Przyrodniczego we Wrocławiu, Wrocław.

Raport o sytuacji banków w 2017 roku, https://www.knf.gov.pl/knf/pl/komponenty/img/RAPORT_O_ SYTUACJIBANKOW_2017_12_61471.pdf(27.05.2018).

Rosa A., 2013, Konkurencyjność sektora banków spółdzielczych w Polsce, The Journal of Management and Finance, $\mathrm{nr} 2$ (1).

Siudek T., Snarski P., Chodera B., 2013, Konkurencyjność banków komercyjnych i spółdzielczych w Polsce, Roczniki Ekonomii Rolnictwa i Rozwoju Obszarów Wiejskich, vol. 100, nr 2, s. 26-36.

Ustawa z 7 grudnia 2000 r. o funkcjonowaniu banków spółdzielczych, ich zrzeszaniu się i bankach zrzeszających, Dz.U. z 2000 r., nr 119, poz. 1252 ze zm.

Zalewska M. (red.), 2013, Bankowość, Wydawnictwo C.H. Beck, Warszawa. 